\title{
The Damage I Have Done to Myself: Physical Intelligence Among College Athletes
}

\author{
Mariah Burton Nelson
}

\begin{abstract}
Thirty years after graduating from Stanford University, I look back on my experience as a star college basketball player and marvel: Why and how did I damage both knees so severely that it is now impossible to walk downstairs without limping? Is lifelong disability an inevitable consequence of college sports? Whose responsibility is it to ensure that college athletes not only learn how to stretch and push their bodies, but also how to care for them? In this article, I describe what I call physical intelligence (the ability to listen to the body's subtle signals and respond wisely to them). I call on college coaches and athletic trainers to advocate openly for physical intelligence education and the long-term health of their athletes, even if such advocacy results in fewer team victories. I assert that the ultimate responsibility for the health of college athletes rests in the hands of the athletes themselves, who can develop physical intelligence the way they develop sports skills - that is, through practice.
\end{abstract}

In 1985, at age 29, I wrote a story for Women's Sports and Fitness magazine about the chronic knee injuries that had developed when I was a sophomore playing basketball for Stanford. "A doctor diagnosed my sharp pain as chondromalacia (deteriorating cartilage under the patella,)" I wrote,

And I began an increasingly complicated physical therapy program. By my senior year, I was reporting to the training room an hour and half before practice and receiving whirlpool and ultrasound treatments, as well as elaborate tape jobs on both knees. I tried heat, ice, aspirin, acupuncture, acupressure, chiropractors, podiatrists, pulsed galvanic stimulators, and quadriceps exercises.

I tried everything everyone could think of except the obvious solution, and the one thing that probably would have been effective: rest.

If only I had understood ten years ago that by playing basketball, I was doing irreparable damage to my knees," I wrote, "maybe I would have listened to the pain and swelling that tried to warn me; maybe I would have made different choices.

And maybe not. Knees are so small and so far from the heart; so insignificant when the gym is overflowing with adoring fans. How trivial knees can seem when an athlete hooks a ball up and over an opponent in a perfect arch; 
how inconsequential those patellar pains become when four teammates are depending on the fifth" to ease the ball through the hoop.

The essay was called "I'm Dancing as Slow as I Can" (Nelson, 1985). The title was a takeoff on a bestseller by Barbara Gordon I'm Dancing as Fast as I Can. In Gordon's memoir, she described her addiction to prescription drugs, her painful withdrawal, and her quest for other sources of joy. In my article, I described my addiction to sports, my painful withdrawal, and my quest for other sources of joy. Gordon also described a "success syndrome" that had seduced her into sacrificing her own health in pursuit of her career goals. I too described a success syndrome that made it nearly impossible for me to hang up my sneakers until the damage was done.

The essay generated more letters than Women's Sports and Fitness had ever received. Clearly, it hit a nerve-or perhaps a ligament. But in the intervening years, even though I wrote hundreds of articles and six books and gave speeches in 50 states to all kinds of audiences, I never really returned to the still-painful subject of my still-painful knees.

Today I will explore this topic_-which I now think of as "the damage I have done to myself" - from the perspective of physical intelligence. I define physical intelligence as the ability to listen to one's body's subtle signals, and respond wisely. I will offer advice on how to become physically intelligent, and I call on coaches, trainers, parents, physical educators, and athletes to share responsibility for teaching and developing this important life skill.

Because I am more storyteller than scholar, this essay will include a series of stories, primarily the story of my relationship with my body: my "experiment of one," as running guru George Sheehan memorably described it.

Somewhat improbably, this will also be a love story, because I have come to believe that those are the stories most worth telling.

\section{Falling in Love With Sports}

I suffered my first athletic injury during a junior high school basketball game.

I had taught myself to play at twelve. My parents installed a hoop in our driveway for my brother. Pete preferred baseball. I was the one who fell in love with basketball: the ball itself, the round, inviting hoop, my teammates, my coaches, the entire improvisational dance.

Even before I met my first team, when I was alone out there in the driveway, I was already in love. I'd caress the ball as it whirled under my palm, guiding it around the cars and potholes. I taught myself to shoot, aiming high so the brown leather sun would sink through the hole quietly, with no ambivalence. I adored the feel of the ball as it spun softly under my hands, the easy arch of the shot, the sweet satisfaction of the swish.

This was what I now think of as the Ecstatic Athletic Quest: the intensely pleasurable pursuit of success.

After hours of reverent, solitary play, I'd wash the ball in our basement sink, carefully rinsing away the driveway's gravel or snow. Later, lying in bed, I'd spin it straight overhead, trying to make it kiss the orange-spotted ceiling before settling in my happy hands. In the morning before school, I'd bounce my beloved off 
my bedroom wall; one hundred little taps with my right hand, one hundred with my left.

As I devoted myself to this basketball, learning to shoot it, catch it, pass it, and care for it, the basketball in return seemed to caress, care for, and even shape me, stretching my fingers, strengthening my willowy arms and legs, widening and lengthening my feet so they'd offer a good place from which I could jump, and on which I could land. Basketball became a gift I could share with friends and strangers. "Here! I'll pass you the ball!" As I grew ever upward, toward the basket, my body itself began to speak of the sport, so that my very presence in a room-head near the ceiling — would prompt people to ask, "Do you play basketball?"

(Later, as my hair turned gray, the question became, "Did you play basketball?")

In one of my first junior-high-school games, a leaping opponent landed on my ankle, tearing some ligaments. I remember the squishy swelling, and the ace bandage that left its lined imprint in my skin.

The crutches intrigued me, with their removable rubber padding for hands and armpits. The crutches could be adjusted if I turned their tiny silver wing nuts, so I could lower them and lend them to shorter friends. Or I could leave them adjusted high, for me, and let friends pole vault down the school halls while I sat, leg propped up, laughing. Negotiating stairs on crutches became another athletic feat, like swishing the ball through the hoop or swimming backstroke in the pool. The crutches became a status symbol, a trophy, proof: I'm an athlete.

Acute athletic injuries tend to happen the way my first one did: as a result of simple accidents or biomechanical failures. Chronic injuries, however, result from a lack of attention, the pleasures of the Ecstatic Athletic Quest overshadowing the body's attempts to signal distress.

When injuries become chronic, one might ask, why not quit? But for the athlete to step off the court is to relinquish one's passion for play. Pleasurable perceptions - two skis caressing a mountain; the welcome ache of powerful thighs kicking through blue water-keep the athlete returning to her sport again and again.

Passion that begins as physical joy can morph into a passion for victory or fame, a passion for beloved coaches and teams, a passion for a lifestyle that affirms the self as highly competent. A backyard game can morph into an athlete's identity, even her raison d'être.

Thus, athletes minimize injuries and return to pools, courts, and fields too soon after injuries. The visceral, social, familial, financial, community, and psychological pleasures of athletic immersion can become so intensely satisfying that they cloud judgment and defy common sense.

I didn't realize how much I had become identified with athletic injuries until a college roommate dressed up as me for Halloween. She borrowed my Stanford basketball uniform, then stood before me dressed in my Cardinal-red and white jersey, shorts, socks, and high-tops. Ace bandages were wrapped mummy-style around each of her knees, extending from socks to shorts. In each hand, she held a plastic bag filled with cotton balls, representing ice.

My roommate had seen me carry ice home from practice every day. She had seen my knees encased in white tape and gauze. To her, this was part of my "uniform"-my standard attire. Yet I was startled to see myself reflected in this way. 
"Sport holds a mirror to a woman's life," LaFerne Ellis Price wrote in The Wonder of Motion back in 1970. But it took a nonathlete to hold a mirror for me, showing me how identified I had become not only with athletic passion and commitment but also with chronic injury.

\section{Classic Love Story}

Mine is a classic athletic love story. The athlete falls in love with sports, and sports reciprocate, offering a haven in which the athlete feels valued, even adored. Eventually this love affair becomes linked with identity. It's like the person who marries, merges, and becomes so identified with the beloved other that her original sense of self is forever transformed.

In the case of the person in love with sports, the loved one is both subject and object. The narcissism of athletic superstars makes sense in this light. It's not just that they love their sport; their sport provides the vehicle through which they can love themselves.

"When I look back, I see a tall young woman who discovered a profound sense of her own beauty and grace by immersing herself in the joyous dance called basketball," I wrote in the "I'm Dancing as Slow as I Can" essay. "What choice did I have but to pursue that path?" (Nelson, 1985).

The athlete who spends every day icing her knees is not just implementing an anti-inflammatory rehab routine. She's nursing her body the way she might an ailing spouse-with a deep emotional attachment and an unspoken bargain: I'll take care of you as long as I get to be in this relationship. It's a relationship that affirms the athlete's core identity-pain notwithstanding.

Every day, young women and men discover their own beauty and grace through sport. No wonder they so often cannot walk—or hobble_-away.

\section{Abusive Relationships}

In my case, the injuries were primarily the result of overuse. I loved sports too much - and kept returning to this attractive lover even when the relationship became abusive.

I also grew up in a sports environment that accepted injuries as "part of the game." No one said, in response to my series of sprained ankles, "I wonder what you could learn from this experience?" No one asked, when the injuries moved from ankles to knees during college, "What is your body telling you?" No one suggested I could stop—or even switch sports.

Perhaps I should note that I am not uncoordinated, injury-prone, or masochistic. Despite my fascination with that first sprain, I did not crave sympathy or attention. I was simply a very athletic child. I swam in my first meet at age five and lettered in five other sports at my two high schools. After playing basketball at Stanford, I spent a year playing for a French professional team, then briefly for four different teams in the first women's professional basketball league in the United States (the Women's Basketball League).

The fact that I am double-jointed probably contributed to my multiple injuries. My knees hyperextend-now known to be a risk factor for injuries. I also 
have knock-knees, meaning my knees tend to cave inward when I land from a jump_another risk factor.

Having played before significant implementation of Title IX, I did not benefit from modern training techniques. But I did lift weights, and I did not specialize in one sport at an early age — a trend that seems to be causing many overuse injuries (as well as burnout) today.

In my midtwenties, I hung up my high-tops and picked up the phone in search of a good surgeon. Bilateral knee surgery did not cure me, but it made walking tolerable. Diverting my Ecstatic Athletic Quest in new directions, I dove into masters swimming, rowing, golf, and water polo, where I could express my passion with minimal pain.

But I still can't walk downstairs without limping. I can't play tennis, volleyball, or my beloved basketball. I can't run, even for a few steps.

We know that many female basketball players have suffered similar injuries. We don't hear about those who drop out or stay on the bench, but we do hear about the famous ones. The University of Connecticut's Rebecca Lobo had two reconstructive knee surgeries on the same knee. Tennessee's Kyra Elzy had two knee surgeries. Connecticut star Shea Ralph had two knee surgeries. Katie SmrckaDuffy of Georgetown had two knee surgeries, two ankle surgeries, and back problems. Tennessee All-American Candace Parker suffered two anterior cruciate ligament (ACL) tears in high school, sat out her first year at Tennessee while undergoing two knee surgeries, then dislocated her shoulder in her senior season. Nykesha Sales ended her senior season at UConn with an Achilles rupture. I could go on and on.

The NCAA tracks injury rates over time through their Injury Surveillance System, but no one I know of is doing longitudinal research to ask 30-year-olds, 40-year-olds, and 50-year-olds about the long-term consequences of their athletic injuries. While we're at it, how about 60-year-olds, 70-year-olds, 80-year-olds? Many people in my generation will live to be 100 . That's about 80 years of life post college sports. How many of us will undergo knee or shoulder replacements, and how many times? How many of us will limp through life?

\section{Suck It Up}

Early in my career as a sportswriter, I met Don Sabo, the leading sports sociologist from D'Youville College in Buffalo, New York. As a former college football player, he had his own injury stories to tell. He had written, in Jock: Sports and Male Identity, of the damage he had done to himself on college football fields and the resultant "broken noses, fingers, toes, and teeth; torn muscles, bruises, bad knees, and busted lips; and the back problems that are with me to this day" (Sabo \& Runfola, 1980, p. 76).

I told him about my damaged knees. "Yes, you got caught up in the bodyeffacing, rather than body-embracing, practices and rationales that typify masculinist sport," said Sabo (Nelson, 1991, p. 7).

To efface is to eliminate or make indistinct as if by wearing away a surface. To embrace is to take up readily or gladly, or to include as a part of a whole. To embrace also means to hug, as one does with a love object. 
In 1994, I wrote The Stronger Women Get, the More Men Love Football (Nelson, 1994). In it, I describe the "manly" sports culture in which men both inflict and receive horrendous personal injuries in the name of a masculinity that is defined by aggression, violence, and a willingness to "suck it up." In this context, playing with pain is noble, playing in agony better. As John Madden has commented, "You gotta give a guy credit when he'll say, 'To heck with my body, I'll run for it.",

You can't get much more body-effacing than that.

Women now run with that same Suck It Up crowd. Tammi Blackstone, for instance, played basketball at Drake University despite her congenitally misaligned kneecaps. "It's basically bone on bone," she told USA Today (Powell, 2009 , p. D5). She received injections of synthetic cartilage. She wore a brace. She did physical therapy. She applied ice. She had surgery. The pain got worse. Walking hurt. She kept playing basketball.

"She goes through the pain for us," said her teammate Haley Sames.

"I also want to be a good role model," said Tammi. "I don't want kids to see me quit just because my knees are bad."

Was that a good reason to grind bone on bone?

Many coaches, trainers, teammates, and fans are quick to praise both male and female athletes who say, "To heck with my body"- or some variation on that theme.

Sa'de Wiley-Gatewood, a senior at the University of Maryland in the 20082009 season, skips many practices due to chronic patellar tendinitis - a condition that causes sharp pain under the kneecaps. "I have old people's knees," the all-American told the Washington Post. (Powell, p. D5)

Wiley-Gatewood's knee problems began her first year in college and got worse. Having been named the Parade Magazine national high school player of the year (over Candace Parker) in 2004, she now plays less than half of each game because of knee pain, resting every three minutes or so. "It's a chronic thing, an overuse injury," says her team trainer, Matt Charvat. "She's a tough kid."

You hear that word tough a lot in connection to sports injuries. Usually it means, "I admire how the athlete plays through pain."

Candace Parker dislocated her shoulder not once but twice in April 2008, right before the Final Four. Legendary University of Tennessee coach Pat Summitt offered Parker a day off before departing for the tournament. Parker opted to try out her shoulder brace instead, joining her teammates for the light practice.

Summitt praised her star athlete afterward. "It's her toughness, it's her focus, it's her desire to win another championship," she told the Associated Press. "I marvel at how mentally strong Candace is" (Rucker, 2008).

I don't fault coaches for admiring commitment and competitiveness. Nor are there black and white answers, in most cases, regarding the time to play and the time to rest. Who is to say that Candace should have sat out that practice rather than experimenting with the new brace?

At the same time, imagine a different culture, one in which coaches praise physical intelligence. In that culture, the athlete in this story might have chosen to rest. And the coach might have said afterward, "I admire her commitment to her 
own body. It's not easy for a competitive person facing an upcoming championship to pay attention to her own body's needs. I marvel at how mentally strong she is."

\section{No Meditating in the Gym}

During my sophomore year at Stanford I lived at a peer-counseling center called The Bridge. In exchange for free housing, I answered the suicide hotline by night and by day taught workshops with titles like, "Altered States of Consciousness Without Drugs" and "How and Why to Meditate." There were chairs in The Bridge, but mostly we lay flat on our backs, our bodies arranged helter-skelter like logs washed up on a beach. We used our own breath to give our bodies "internal massages," visualized achieving our goals, and practiced "progressive relaxation," whereby we gradually relaxed every muscle group, starting with the scalp and trying to work our way down to the toes without first succumbing to sleep.

As a psychology major, I was an enthusiastic teacher and student at the Bridge, where personal growth and spiritual enlightenment seemed worthwhile and possibly attainable goals.

Trying to create a bridge, so to speak, between two extracurricular activities, I started arriving early at the Stanford gym and meditating before practice. I'd sit cross-legged in the bleachers, close my eyes, and relax. Then I'd take myself through a series of visualizations: shooting free throws, for instance, and imagining making every one. I had read the research and believed then (as I do now) that mental practice can be an effective adjunct to actual practice.

Soon one of my teammates joined me. Then a second. This was the midseventies in California; everyone was interested in such subjects.

But before long, my coach vetoed the practice. Imagine our surprise when we showed up early one day and saw a sign on the door: "No meditating in the gym"!

I never learned what the coach found objectionable. Mental practice? Physical relaxation? Personal insight? Spiritual searching?

A former Stanford field hockey player offered a possible explanation when I told her about the thesis of this essay and she reacted as if my proposal were heretical. "Physical intelligence is contrary to everything coaches want from athletes. They want compliance. They want you to forget about your own body while striving for the greater good."

True, coaches expect and even need athletes to be inured to the minor scrapes and bruises that happen in the course of any rigorous sport. Coaches receive raises based on how many "W's" show up in the win-loss column. Their very careerseven at the Division III level—are dependent on the performance of others.

This presents a conflict of interest. The coach who errs on the side of caution or compassion, who urges a mildly injured athlete to rest or retire, risks reducing her own salary, and her chances for advancement, by decreasing her overall W's, as well as the team's. How can coaches realistically be expected to put the longterm health of their athletes above their own career goals and above the team's chances of winning championships-especially when such calculations are imprecise at best? 
At the same time, doesn't it seem an odd omission that coaches, physical education teachers, and parents don't routinely teach young people reverence and respect for their own physical beings? We teach them how to achieve amazing physical feats. But we rarely teach them to pay attention to the day-to-day biofeedback they are receiving: to recognize when they're sore or tired, when they need to stretch or rest. Repeatedly praised for their "toughness," athletes learn to suck it up: to ignore the chronic injuries that might be crippling them for life.

\section{The Athlete's Dilemma}

To improve, athletes must leave their comfort zone, literally. They must inflict a mild form of physiological injury, which is a precursor to muscular development. During a strenuous workout, minute muscle fibers tear. Bodies then heal themselves, reattaching those fibers in ways that build stronger muscle.

This is why athletes take rest days after weight workouts: bodies need time to rebuild the damaged muscle tissue. This causes some soreness, generally perceived to be "good hurt."

To a trained athlete, "good hurt" feels different from "bad hurt." There are gray areas, but most athletes can tell the difference from tiny muscle tears (regular training soreness) and a major muscle tear (ouch!). They know that in general, muscle pain is okay and joint pain is not. They might not know if a swollen foot indicates a torn ligament, a bruised heel, or a broken bone, but they know it's not smart to keep running. The pain tells them that.

Yet their love of sport tells them, "Stay in the game!" Their passion for play says, "You can heal later!"

And young bodies do heal from numerous assaults. So the athlete stays in the game, and the coach praises their toughness, and the player gets the message: Suck it up.

What's an athlete to do? How can a young athlete choose caution over competition, and prudence over praise, when faced with nagging but tolerable pain in distant joints? How can a college junior who "lives to play" soccer choose to sit on the bench because a tendinitis-inflamed shoulder, or a swollen knee, or seemingly minor injuries might—but might not—have long-term consequences?

How can a 19-year-old on a full scholarship inform his 40-year-old coach, perhaps a local or national hero in his own right, that he should probably sit out the Big Game because his elbow is sore (again) and he's concerned about being able to play backyard catch with his kids 20 years from now when he's a father?

He can't, really — not when such a decision would be perceived as insubordination or insanity.

More likely, that athlete will beg to play. In Candice Wiggins' junior season at Stanford in 2007, she injured her hamstring, then ankle, then the same hamstring. Listen to this San Francisco Chronicle description of her conversations with Coach Tara VanDerveer:

"With each injury rehab, Wiggins wages a one-woman propaganda campaign to convince her coach that Candice is fine-fine-fine and good to go.

Wiggins leaves text messages: "I'm good, Tara!"

VanDerveer messages back: "Ice." 
There is a huge trust bond between the two, but VanDerveer knows all about crazy basketball passion, so she will grab Wiggins by both shoulders and say, "Look right at me, Candice. How. Does. Your. Leg. Feel?"

VanDerveer looks for a telltale averting of the eyes. Wiggins swears she feels great. But does that mean she's really OK, or that she's really good about lying so she can play?

"She's very convincing," VanDerveer said.

During Sunday's first half, a Stanford assistant coach told VanDerveer that Wiggins was limping. Out came Candice, who looked at her coach questioningly.

"You were limping," VanDerveer said.

“No I wasn't!" Wiggins said. (Ostler, 2007)

Here we see that even a coach with the best intentions cannot know what a player is feeling. A player cannot quite know either, because in the heat of a game endorphins mask pain. And who can fault an athlete for focusing on the game rather than her body when that game focus helps her achieve excellence?

And who can fault an athlete for being seduced not only by the Ecstatic Athletic Quest itself but also by the fame and fortune that may accompany it? College sports offer an alluring array of benefits these days: scholarships, clothes, equipment, hearty meals, travel, media coverage, accolades from peers and professors, family pride, and a sense of belonging to a very cool, very popular team.

In my case, the opportunity to play professional basketball-first in France, then in the first women's professional league in the United States-proved irresistible. ("You're going to offer me money to play basketball?" I almost responded when notified of the first draft. "Are you kidding?") The higher paychecks the Women's National Basketball Association now offers must prove equally irresistible to contemporary college athletes.

Nevertheless, the athlete who hopes to stay active throughout his or her lifetime must learn to pay attention to her own body - and respond wisely to it, even when that response entails walking away. As with any skill, this takes practice.

\section{What Is Physical Intelligence?}

My concept of physical intelligence is founded on three assumptions:

1) Our bodies generally know what they need and try to tell us.

2) Every body is unique.

3) Our relationship with our bodies is the most important and most enduring relationship of our lifetimes.

Based on those assumptions, I define physical intelligence as the ability to listen to the body's subtle signals and respond wisely.

There are two key parts of this definition:

- The ability to listen to the body's subtle signals: "Body language" includes vocabulary such as discomfort, stiffness, fatigue, and hunger; more pleasant sensations (a sense of strength, agility, balance, endurance, relaxation, peace, happiness, vitality, arousal); and emotional states (fear, loneliness, joy)—all of which can affect physical performance. 
- And respond wisely: Knowing what your body is "saying" is worthless unless

you respond wisely. Being aware of a sore ankle, for instance, is not valuable unless you stop jumping up and down on it.

Harvard professor Howard Gardner first proposed a theory of multiple intelligences in 1983. Gardner's intelligences include linguistic, logicalmathematical, spatial, musical, interpersonal, intrapersonal, naturalist, and bodily-kinesthetic. However, the bodily-kinesthetic intelligence as defined by Gardner focused on knowing how to move (swim, dance, juggle) rather than knowing how to listen and respond wisely, which is my interest.

\section{Proprioception}

We are all designed for physical intelligence. Just as we have brain cells with which to think, we have body cells designed to monitor physical activity. These microscopic nerve cells, located in muscles, joints, ligaments, and connective tissue, are called proprioceptors.

Sometimes known as the sixth sense, proprioception is the ability to sense the position, location, and movement of the body and its parts. In John McPhee's book about Bill Bradley's playing days at Princeton, Bradley is quoted as referring to proprioception as "a sense of where you are" (McPhee, 1965).

"It's a genuine sense, just as real as taste, sight, or smell," explains Frank Forencich, a functional fitness expert and author of Exuberant Animal and Play as if Your Life Depends on It.

Fortunately, this system is trainable; we can increase our sensitivity with playful, functional movement. This orientation gives new meaning to our experience in the gym or on the track. We aren't going out just to pump muscles or challenge our cardiovascular system; we're going there to make our bodies more sensitive and more intelligent. (Forencich, 2006, p. 255).

But college sports are less focused on sensitivity and intelligence than on performance.

\section{Obstacles to Physical Intelligence}

We are not in the habit of paying attention to our bodies. Some of us don't want to. Many women feel reluctant to examine their own breasts, and many men feel reluctant to admit to any illness, weakness, or vulnerability.

Many people do not really live in their bodies. They're not "at home." When sleepy, people drink caffeine rather than taking a nap or making plans to get to bed earlier. When hungry, we choose snacks that are not nourishing. When full, we don't stop eating.

If you have a problem with your body, you're expected to seek a health care practitioner to fix it. That person will ask you to describe your symptoms, but rarely will you leave the encounter feeling empowered to solve your problem. Instead, the expert will prescribe a treatment, and you will remain in the role of consumer — not the one responsible for your own primary care.

Although proficient at sports, athletes don't necessarily learn how to use their bodies in ways conducive to long-term health. "In giving priority to sport, we fail 
to teach even the basic elements of functional physical education," says Frank Forencich (2006). "In effect, here's what we're telling our children: 'We'll teach you how to throw a baseball, but we won't teach you how to lift a box, move a piece of furniture, or hike on a trail. We'll teach you how to set up a zone defense, but we won't teach you how to develop useful balance and strength in your legs."'

Learning physical intelligence takes time. It's slower than drugs or surgery. It can be difficult to figure out what your body is saying, what implications that might have, and then experiment with lifestyle adjustments. It's a lot easier to suck it up.

\section{First Key to Physical Intelligence: Awareness}

Now I'll expound a bit on the two aspects of physical intelligence: awareness and action.

About twelve years ago, I was diagnosed with asthma. "We can try medications, but first I want you to avoid the things you're allergic to, because they trigger asthma attacks," my pulmonologist recommended.

"I don't know what I'm allergic to," I responded. "I've never had allergy tests."

"Oh, I bet you do," he said gently.

"Dust, pollen, autumn leaves, yogurt, milk, cottage cheese, and my dog," I said.

Sure enough, I am allergic to those things. When I avoid them (or, in the latter case, avoid sleeping with them), I can avoid both asthma attacks and asthma medicine. My body had been explaining that allergic/asthmatic reaction to me for years: I used to cough every morning after my bowl of yogurt. (My type of asthma manifests as coughing rather than wheezing). How obvious! But I hadn't been paying attention until the coughing became so chronic I felt like I was drowning.

We know more than we allow ourselves to know-because knowing means facing our habits and fears. What if we have to give up something we love, such as yogurt, a dog, or a sport?

Paying attention is also challenging because our bodies change, minute-byminute and year-by-year. Self-knowledge requires an ongoing process of listening and responding.

We have other priorities - making money, taking care of people, getting from here to there - that can take precedence over what our bodies would like us to do. We have conflicting messages and desires. The tongue might say, "Feed me carrot cake" while the stomach says, "I'm already full from dinner."

And it's difficult because it's not just a physical and intellectual process, this communication between body and brain. We have feelings about our needs and desires. We might feel guilty or disappointed about pain or limitations. We might grieve our loss of agility or ability. We might feel victimized: "I shouldn't be injured! I was taking care of myself!"

To become physically intelligent, we must learn to listen-not only to joint pain, but also to the entire ecosystem known as our body.

"Really great athletes baby their bodies," says Olympic swimming gold medalist Nancy Hogshead. "You push yourself right up to the point where your body wears out, but you never cross over that point." 
Hogshead is describing what runners call redlining, a term borrowed from auto racing. The redline is the mark on the RPM gauge that signals the maximum speed at which the engine is designed to operate without causing damage to the engine or its parts. Runners use the term when discussing the attempt to train right up to, but not past, the point of self-destruction. The problem is, it's often impossible to know where the redline is until it's too late. It's also impossible to know how much redlining a body can handle without causing irreparable harm.

"Rather than seeing your soul and your body as two separate things, you have to be teammates," says Hogshead, now a sports lawyer at the Florida Coastal School of Law. "The body is full of wisdom, and so is the mind. You have to get over the finish line together."

\section{Body Language}

How does a body communicate what it needs? Sometimes it screams: "Broken bone!" "Seizure!" More often, it whispers: "Stiff neck." "Sneezing." "Discomfort." All day long, our bodies offer a moment-by-moment report:

1) I'm hungry or thirsty.

2) I'm tired or sleepy.

3) I'm sore, stiff, itchy, or injured.

4) I'm sick or uncomfortable.

5) I'm warm or cold.

6) I'm lumpy, discolored, or sending other distress signals.

7) I'm carrying too much or too little weight.

8) I'm strong or weak, tense or relaxed.

9) I'm balanced or off-balance.

10) I'm able to see, smell, feel, taste, and hear well, or not.

11) I'm emotionally content or upset.

12) I'm satisfied, balanced, competent, refreshed, vital, alert.

13) I crave touch or solitude.

14) I need to void my bladder or bowels.

15) I need to breathe, stretch, or move.

Still, a body cannot provide all of the available information. Tests (x-rays, MRI's, Pap smears, mammograms, prostate exams, colonoscopies) can detect internal damage that we can't necessarily diagnose on our own. So we need to seek help from professionals_-but begin with our own inner knowing.

\section{Second Key to Physical Intelligence: Action}

The most common response to an unwelcome message from the body is denial. Michelle Wie tried to play golf throughout 2007 despite a broken wrist, which led to a series of missed cuts and withdrawals. Asked later what she might have done differently when she first broke her wrist, she said, "I would not have played. I was in no condition to play. I don't know what I was thinking. My wrist was 
broken, but I wasn't going to let the wrist break me. It was just that mentality where it's like, I'll just take more painkillers and just play through it."

This is why I use the phrase "respond wisely."

I saw an orthopedist recently for a sore elbow. He explained that the tendinitis was probably caused by the fact that my elbows (like my knees) hyperextend. When I straighten my arm, it goes overboard, bending backward. This is true for many women, but can stress joints, especially when you're supporting your weight on your arms, as I do during yoga practice.

The doctor prescribed an anti-inflammatory drug. But what cured the problem is this: I stopped hyper-extending my arms. Now I do yoga slightly differently, lift weights slightly differently, and even swim slightly differently. My elbow feels fine and I'm proud of myself, frankly. Physical intelligence is inherently rewarding.

In Warrior Girls, Michael Sokolove's provocative and important 2008 book about the disproportionate ACL epidemic among women athletes as compared with men, the New York Times journalist concludes that women "may endure more pain, often to their detriment, because they feel they have something to prove" (Sokolove, 2008, p. 85).

That might be true in some cases, but I don't think the average 20-year-old student is staying on the basketball team to fly a feminist banner aloft. If she's on the team despite overuse injuries, she might feel reluctant to be a "quitter." She might feel committed to her coach and her teammates. She might feel concerned about losing her scholarship. But I believe that the ones who stay and play despite chronic pain are primarily the ones who literally cannot conceive of another way of life. They are athletes. They cannot not be athletes.

In college, when my knees' cries of pain became too loud to ignore, I consulted a doctor who, in response to my questions about my future, warned, "The strain you're putting on your knees now may cause you to develop arthritis by the time you're forty." At twenty, forty was light years away and arthritis was no more imaginable than cataracts. But this is developmentally appropriate: teens and young adults notoriously feel invulnerable and unable to fully appreciate the consequences of their actions.

Now my knees and I have a deal: If I don't run, jump, or pivot, and if I lift weights three times a week to sustain quadriceps strength, and if I pay careful attention and make adjustments to my workout routine as needed, I can enjoy what I have come to think of as the sitting and floating sports (cycling, rowing, swimming), and can also walk (including on golf courses) without pain. But I still must listen and respond on a daily basis - not only to my knees, but also to the rest of this complicated package of ambition and limitation.

"[Women] have been raised to fear the yes within ourselves, our deepest cravings," wrote the late author Audre Lorde (1978, p. 6). We also fear the deepest no. For athletes, to be "benched" is a form of torture. Yet to say no-for a day, a season, or a lifetime_-can mean saying yes to health.

\section{Institutionalized Physical Intelligence}

A variety of programs designed to prevent ACL tears (such as the Jump-ACL Study at the University of North Carolina and the flagship program at Santa Monica Orthopedics) are receiving attention these days, for good reason. These 
programs include strength and agility training, proper landing techniques, and proprioceptive/balance/coordination training. Athletes are taught to land softly, land with their knees bent, and land with their knees aligned over their toes, not letting knees collapse inward.

These programs show promise at preventing ACL tears, a very encouraging development. In the course of any athletic contest, much of what the body does will be unconscious based on years of training, repetition, and discipline. If athletes learn through practice to "automatically" land more softly, with correct alignment of feet and hips, that's important.

I wonder whether the training also helps athletes develop a practical form of physical intelligence that might help them avoid other injuries as well. Because the more an athlete consciously understands what functional fitness feels like and how to make adjustments when minor problems arise, the more empowered she will be to stay strong over the course of her lifetime. As with any skill, physical intelligence improves with practice, so the physically intelligent athlete will develop an effective relationship with her whole body (not just her muscles and joints), one that will grow more satisfying and healthy over time.

George Sheehan first used the phrase "We are each an experiment of one" in reference to distance runners. Each of us is a sort of mobile science experiment, he said. He encouraged people to learn from personal observations, sensations, and intuition, and then adjust their training accordingly. "Listen to your body," he said. "We are all unique, never-to-be-repeated events."

Sheehan questioned the value of tests measuring blood, urine, oxygen, and body fat composition. "There is no substitute for learning to live in our bodies," he said. "All the tests and all the machines in the world will fail if we do not first become good animals."

About 15 years ago, my father saved his own life. While driving to a golf game at age 69, he felt pain radiating down his left arm, did a U-turn, and drove himself to the hospital instead. "This feels like a heart attack," he said to the nurse who met him in the emergency room. A few minutes later, he suffered a massive heart attack, was wheeled into surgery, and underwent a quadruple bypass. Now 85 , my father's heart is strong. He saved his life by listening to the language his body was speaking: in this case, the language of pain.

My father, a physician, is attuned to what physical symptoms signify. Less physically intelligent people, eager to play golf or unwilling to admit weakness or vulnerability, might have driven to the golf course instead. Many college athletes are "driving to the golf course," in effect, when they continue to play sports despite the warning signs their bodies are giving them.

\section{Whose Responsibility?}

Whose responsibility is it to teach athletes to become "good animals," as Sheehan put it? Parents, perhaps, or youth-league and high school coaches. But if this training has not been imparted by the time the athletes are in college, four other options remain: coaches, athletic trainers, physical educators, and the athletes themselves.

Let's consider coaches first. A few years after I graduated from Stanford and retired from my brief stint as a professional basketball player, I was hobbling 
around Santa Cruz, California, trying to figure out what to do with my life, when I ran into a women's basketball coach from another school in Stanford's conference. I was using a cane and had not yet found a surgeon who could offer me any hope. The coach and I chatted about my predicament.

"I always knew you were permanently damaging your knees," she told me matter-of-factly. "I could tell by how extensive the taping was. When I see someone with tape like that, or huge braces, I know this is going to be a lifelong problem."

I was too flabbergasted to ask, "Did it ever occur to you to intervene?"

As the coach of an opposing team, she was not in a position to intervene. But is it a coach's job to look out for the overall health and well-being of his or her own athletes? According to the Women's Basketball Coaches Association, the answer is yes. Their Code of Ethics includes this mandate: "Place the health and welfare of student-athletes above team goals, respecting the advice of trainers and medical personnel" (Women's Basketball Coaches Association, 2009).

Surely, this is not easy-which must be why they spelled it out in the Code of Ethics. Surely, coaches are tempted to place team goals above the health and welfare of student-athletes and to ignore the advice of trainers and medical personnel. A coach can't win without athletes.

Yet I believe that most coaches try to do the right thing. Coaches commit considerable resources to injury prevention, and there must be many times when, after considering recommendations from a physician or trainer, a concerned coach makes the call: The athlete will rest. After all, coaches are former players, usually, and probably have their own "Damage I Have Done to Myself" stories to tell. Might the team lose some games because of such decisions? Yes; hence, the conflict of interest.

The National Athletic Trainers Association has its own code of ethics, which states, "Members shall not . . . participate in any arrangement that exploits the patient" (National Athletic Trainers Association, 2005, p. 2). Trainers have plenty of informal opportunities, while taping ankles or knees, to encourage athletes to pay attention to their bodies and respond wisely. They already educate athletes in such basics as, "stretch only until you feel mild tension," and "if you sense that something isn't right, come talk to me." Seems that trainers-and the physicians who work with them-could easily integrate more physical intelligence education into their conversations with athletes.

How about physical educators? The committed physical educators I know eagerly teach students about bodies: coronary heart disease risk factors, for instance. They teach fitness and sport skills. They help them to develop healthy habits. But as far as I can tell they're not really offering an experiential approach, not asking them to explore their own sensations. When I talk about physical intelligence with members of my organization, the American Association for Physical Activity and Recreation, they sound intrigued, which gives me hope.

How about the athletes? To become mature people who know and respect their bodies' needs, athletes must have opportunities to listen to their bodies, respond using their best judgment, and live with the consequences. Sports are often credited with teaching leadership, but leadership is developed only when people get chances to think (and feel) for themselves. 
So who should be responsible: parents, coaches, trainers, physical educators, or athletes? All of the above. Physical intelligence should start with parents in the home and physical educators at all levels of school and college. Athletic trainers should teach athletes how to listen and how to respond. And athletes themselves must take primary responsibility for their own health and well-being, as all of us must.

But the college coach sets the tone. Physicians must continue to provide information and guidance too, but no doctor can know more about an athlete's body on a daily basis than he or she can. Coaches must encourage athletes to pay attention and make at least some of their own decisions.

\section{Who Is Teaching Physical Intelligence?}

Who is teaching physical intelligence outside the college setting? Here are a few examples:

- Yoga Nitra, a guided meditation, is designed to help people sense what's going on in their bodies so they can benefit from that information-for instance, by noticing muscle tension and learning to relax.

- The CHEK (Corrective Holistic Exercise Kinesiology) Institute in Encinitas, California, teaches what founder Paul Chek calls movement intelligence, training clients to become aware of their movements and the information their bodies are absorbing.

- The Alexander Technique teaches students to understand and experience the relationship between their head and spine, thus reducing neck tension and spine compression and freeing the person to use the skeleton and musculature in a more natural, efficient way.

\section{Is Excellence in Sport Compatible With Good Health?}

Despite knee damage that began in college and limits me still, and despite almost a half-century of myriad athletic contests and satisfactions, my college basketball career remains the pinnacle of my sports experience. "My finely tuned body brought me incredible pleasure: finely tuned teams magnified that pleasure to the point of ecstasy," I wrote in "I'm Dancing as Slow as I Can." To this day I carry with me visceral knowledge about teamwork, leadership, success, strength, and discipline that I could not have received elsewhere in quite the same way.

However, when people see me limping and ask, "Was it worth it?" I do not say yes.

“Ask me again when I'm 80," I answer. “Or 100."

How many knee and shoulder surgeries or replacements, and how many years of pain and disability, might it take for me-or other former college athletes- to say, "You know what? That was not worth it!"

We need to survey former college athletes - not only in middle age, but in old age - to find out how their bodies held up, or didn't, and how they feel about the "sacrifices" for which they were praised when young. Wouldn't it be ironic (and 
sad) if former college athletes suffer from more disability in old age than people who never exercise regularly? But if that's what the research shows, who would be surprised?

Sport is missing a key ingredient that has the potential to reduce injury rates and to produce athletes who, upon graduation, are prepared for a lifetime of agility, strength, fitness, and fun. Let's start a conversation about this missing ingredient: physical intelligence.

Let's start teaching athletes to design their own personal Injury Surveillance Systems. As part of this surveillance, athletes should ask themselves such question as,

- What is my body trying to tell me?

- How might I respond wisely to the subtle signals my body is sending me? and

- What might be the long-term consequence of my current behavior?

In a popular song, The Clash asks, "Should I Stay or Should I Go?" Athletes need to ask themselves related questions:

- Should I play or should I go?

- Should I play today, or rest today?

- Should I play this sport, or switch to another sport that's easier on my joints?

- $\quad$ Should I play this way, or learn a less stressful way to play?

My title, "The Damage I Have Done to Myself," comes from a poem by the ancient Sufi poet, Kabir (2007, p. 53):

... The daily sense of failure goes away,

The damage I have done to myself fades,

A million suns come forward with light,

When I sit firmly in that world.

The damage I have done to myselffades. Such self-forgiveness is necessary if we wounded warriors are going to come to terms with the fact that we did irreparable harm to ourselves when we were young.

Here are two more lines from the poem:

We are all struggling; none of us has gone far . . .

I like that humility: We are all struggling. None of us has gone far. It implies lifelong learning — appropriate for the educational context of college sports.

Let your arrogance go, and look around inside.

Physical intelligence requires letting one's arrogance go and looking around inside.

Like the rival coach who worried about my elaborately taped knees, I look at college athletes today and worry about their future.

Are they destined to limp through life? Not if we redefine excellence to include not only excellent performance but also excellent commitment to one's 
own health. And not if we give athletes the training and support they need to develop loving, committed relationships with their own bodies. After all, those bodies are what will stay with them, for better or for worse, in sickness or in health, until the very end of the game.

\section{References}

Forencich, F. (2006). Exuberant animal. Bloomington, IN: Author House.

Kabir. (2007). The Kabir book: Forty-four of the ecstatic poems of Kabir [trans. Robert Bly]. New York: Houghton Mifflin.

Lorde, A. (1978). Uses of the erotic: The erotic as power. Trumansburg, NY: Crossing.

McPhee, J. (1965). A sense of where you are. New York: Farrar, Strauss, and Giroux.

Nelson, M.B. (1994). The stronger women get, the more men love football: Sexism and the American culture of sports. New York: Harcourt Brace.

Nelson, M.B. (1991). Are we winning yet? How women are changing sport and sports are changing women. New York: Random House.

Nelson, M.B. (1985), "I'm Dancing as Slow as I Can," Women's Sports and Fitness, June 1985.

Ostler, S. (2007, March 5). Wiggins injured? Tell her opponents. San Francisco Chronicle.

Powell, C. (2009, Jan. 25). Terps' Wiley-Gatewood gives all that she can. The Washington Post, p. D5.

Price, L.E. (1970). The wonder of motion: A sense of life for woman. Terre Haute: LaFerne Ellis Price.

Rucker, B. (2008, April 3). CBKB: Tennessee's Parker cleared to play vs. LSU. The Honolulu Advertiser.

Sabo, D.F., \& Runfola, R. (1980). Jock: Sports \& male identity. Englewood Cliffs: Prentice-Hall.

Sokolove, M. (2008). Warrior girls: Protecting our daughters against the injury epidemic in women's sports (pp. 85). New York: Simon \& Schuster. 